\title{
The demand of senior secondary school youth for health education in the field of natural family planning
}

\section{Zapotrzebowanie młodzieży ponadgimnazjalnej na edukację zdrowotną z zakresu naturalnego planowania rodziny}

\author{
Agnieszka Błachno ${ }^{1, A-D}$, Ewa M. Kobos ${ }^{1, A, C-F}$, Grażyna Bączek ${ }^{2, E, F}$ \\ ${ }^{1}$ Department of Social Nursing, Faculty of Health Sciences, Medical University of Warsaw, Poland \\ ${ }^{2}$ Department of Obstetrics and Gynecology Didactics, Faculty of Health Sciences, Medical University of Warsaw, Poland \\ A - research concept and design; $\mathrm{B}$ - collection and/or assembly of data; $\mathrm{C}$ - data analysis and interpretation; \\ $D$ - writing the article; $E$ - critical revision of the article; $F$ - final approval of the article
}

Address for correspondence

Ewa M. Kobos

E-mail: kobewa@interia.pl

Conflict of interests

None declared

Received on November 17, 2017

Reviewed on January 7,2018

Accepted on February 2, 2018

DOI

10.17219/pzp/84983

\section{Copyright}

( 2018 by Wroclaw Medical University

This is an article distributed under the terms of the

Creative Commons Attribution Non-Commercial License

(http://creativecommons.org/licenses/by-nc-nd/4.0/)

\begin{abstract}
Background. "Natural family planning" is a way to plan to achieving or postponing conception of a child. Issues concerning natural family planning, sexuality and related topics have been controversial for many years and are considered taboo.
\end{abstract}

Objectives. Determining the demand of senior secondary school youth for health education in the field of natural family planning based on the students' knowledge and their opinions on the organization of education.

Material and methods. The study comprised 100 senior secondary school and technical secondary school students. A questionnaire survey was used to collect the research material. The analysis of the results was performed using the PQStat v. 1.6 statistical package. The differences between variables and the level of knowledge were analyzed using the Fisher's test.

Results. A satisfactory level of knowledge about natural family planning was found in $7 \%$ of the subjects. Students from the study group had the lowest level of knowledge on thermal and mucus methods, the highest on cervical observation. Students acquired the information about natural family planning mainIy from the Internet, magazines and their colleagues. In the opinion of $81 \%$ of the students, implementation of the theme of natural family planning at school is justified. Seventy percent of the students confirm their willingness to participate in natural family planning classes organized at school. In the opinion of nearly half of the surveyed students, natural family planning classes should be conducted by a doctor, a nurse and a school teacher.

Conclusions. The insufficient level of students' knowledge about natural family planning justifies the need to include this subject in the curriculum of senior secondary schools in a broader context than before. Education on natural family planning requires stronger involvement of healthcare professionals as a credible source of information.

Key words: health education, student, natural family planning 


\section{Streszczenie}

Wprowadzenie. Naturalne planowanie rodziny (NPR) jest sposobem na zaplanowanie bądź też odłożenie poczęcia dziecka. Zagadnienia dotyczące naturalnego planowania rodziny, seksualności i tematów z nimi związanych od wielu lat budzą kontrowersje i są określane jako tabu.

Cel pracy. Określenie zapotrzebowania młodzieży ponadgimnazjalnej na edukację zdrowotną z zakresu naturalnego planowania rodziny na podstawie wiedzy uczniów oraz ich opinii na temat organizacji edukacji.

Materiał i metody. W badaniu udział wzięło 100 uczniów liceum ogólnokształcącego i technikum zawodowego. Do zebrania materiału badawczego wykorzystano kwestionariusz ankiety. Analizę wyników przeprowadzono za pomocą pakietu statystycznego PQStat v. 1.6. Różnice między zmiennymi a poziomem wiedzy przeanalizowano testem Fishera.

Wyniki. Dostatecznym poziomem wiedzy na temat NPR wykazało się tylko 7\% uczniów. Najniższy był poziom wiedzy dotyczącej metody termicznej oraz śluzowej, najwyższy - metody obserwacji szyjki macicy. Informacje na temat naturalnego planowania rodziny uczniowie czerpią głównie z Internetu, czasopism oraz od kolegów. W opinii 81\% uczniów realizacja tematyki naturalnego planowania rodziny na zajęciach w szkole jest zasadna. Aż 70\% uczniów potwierdza chęć wzięcia udziału w zajęciach z naturalnego planowania rodziny organizowanych na terenie szkoły. W opinii blisko połowy badanych zajęcia z zakresu naturalnego planowania rodziny powinny być prowadzone przez lekarza, pielęgniarkę oraz nauczyciela ze szkoły.

Wnioski. Niedostateczny poziom wiedzy uczniów na temat naturalnego planowania rodziny uzasadnia konieczność uwzględnienia tej tematyki w programie nauczania szkół ponadgimnazjalnych w szerszym niż dotychczas wymiarze. Edukacja z zakresu naturalnego planowania rodziny wymaga większego zaangażowania pracowników ochrony zdrowia jako wiarygodnego źródła informacji.

Słowa kluczowe: edukacja zdrowotna, uczeń, naturalne planowanie rodziny

\section{Background}

"Natural family planning" is a way to plan achieving or postponing conception of a child. A woman observes the symptoms and phases of fertility and infertility in her menstrual cycle and refrains from sexual intercourses in the fertile period unless she is planning pregnancy. ${ }^{1,2}$ Issues concerning natural family planning, sexuality and related topics have been controversial for many years and are considered taboo. Even though the number of pregnancies among the young has markedly decreased in recent years, this problem still exists in our country. ${ }^{3}$ According to the Statistics Poland, in 2013, there were about $2 \%$ of births given by girls under the age of 18 , including 48 children born by those aged 14 and younger. ${ }^{4}$ This data shows early sexual initiation among young people, which is classified as risky behavior. Early sexual initiation involves the risk of early procreation and parenting, sexually transmitted infections and dangerous sexual behaviors. ${ }^{5,6}$

Sexual awareness is a very difficult process for young people today, which is due to the lack of sex education that has its origin in the family, then at school and medical institutions. ${ }^{5}$ Therefore, there is an obvious need to motivate parents, teachers and healthcare professionals - gynecologists, nurses and midwives - to spread knowledge on sexual health. The sexual awareness of a young person should be the foundation for building a later mature life. In consequence, young people will be able to enjoy wellbeing not only in the sexual, but also in the physical, psychological and emotional sphere. ${ }^{5}$

Under the curriculum of general teaching, sex education is implemented through the subject "Education for Family Life". ${ }^{7}$ According to Długołęcka, sex education is "a part of interdisciplinary education about human sexuality in the biological, health, social, cultural, historical, and even political dimension". ${ }^{8}$ Under the school curriculum, every year, $14 \mathrm{~h}$ are devoted to Education for Family Life, including $5 \mathrm{~h}$ with division into groups of boys and girls. Underage students may participate in Education for Family Life classes if their parents or legal guardians give their written consent. An adult student independently decides whether or not he or she will attend the classes. Education for Family Life classes are not subject to assessment and do not have an influence on the promotion or graduation of students. ${ }^{9}$ Each of the sex education goals defined by the Polish education system has been adapted to the stage of the educational process, thus, we can distinguish primary school, junior secondary school and senior secondary school goals. ${ }^{10}$

The objective of this study was to determine the demand of senior secondary school youth for health education in the field of natural family planning based on the students' knowledge and their opinions on the organization of education.

\section{Material and methods}

A survey questionnaire containing 35 questions was used to collect the research material. Ten questions concerned the students' opinions and attitudes and 25 were knowledge questions about natural family planning. The questions about knowledge included 5 thematic categories (5 questions each): the menstrual cycle, natural family planning, the thermal method, the mucosal method, and cervical observation. For analyses, 4 lev- 
els of the students' knowledge were determined in each question category: insufficient (1-2 points), satisfactory (3 points), good (4 points), very good (5 points), and total: insufficient ( $\leq 13$ points), satisfactory (14-17 points), good (18-21 points), and very good (22-25 points). The results were analyzed using the PQStat v. 1.6 statistical package (PQStat Software, Poznań, Poland). Differences between the variables and the level of knowledge were analyzed using the Fisher's test. The test probability of $\mathrm{p}<0.05$ was accepted as significant.

According to the regulations, the Bioethics Committee of the Medical University of Warsaw, Poland, does not issue opinions on surveys and noninvasive scientific research.

The study comprised $76 \%$ women and $24 \%$ men. Fiftytwo percent of the students were 18 years old and $48 \%$ were 19 years old. The vast majority (79\%) of the students came from rural areas. Half of the subjects attended a senior secondary school, half a technical secondary school. Most students (97\%) declared Roman Catholic faith. Sixty percent of junior secondary school students and $70 \%$ of senior secondary school and technical secondary school students declared participation in Education for Family Life classes every year at school.

\section{Results}

According to the data analysis, $71 \%$ of the students had insufficient knowledge about the menstrual cycle and $25 \%$ presented satisfactory level of such knowledge. In the category of natural family planning questions, $65 \%$ of the students had insufficient, $20 \%$ satisfactory and $11 \%$ good knowledge. Eighty-three percent of the students showed insufficient knowledge about the thermal method. Knowledge about the mucus method was insufficient in $88 \%$ of the subjects and satisfactory in $11 \%$. In the category of cervical observation questions, the students showed the best level of knowledge. Twenty-four percent of the subjects had satisfactory and $14 \%$ good knowledge. Ninety-three percent of the students showed insufficient overall knowledge about natural family planning. A satisfactory level of knowledge was found in $7 \%$ of the subjects. The results are presented in Table 1.
The analyses did not show any correlation between sex, place of residence, type of school, participation in Education for Family Life classes, and the level of knowledge about natural family planning. The data is shown in Table 2.

In the opinion of $48 \%$ of the students, it is "quite" reasonable to run natural family planning classes. Thirtythree percent of the subjects believe that classes on this

Table 2. The total level of students' knowledge and selected variables Tabela 2. Poziom wiedzy uczniów ogółem a wybrane zmienne

\begin{tabular}{|c|c|c|c|c|}
\hline \multirow{2}{*}{ Variable } & & \multicolumn{2}{|c|}{$\begin{array}{l}\text { Total level of students' } \\
\text { knowledge }\end{array}$} & \multirow{2}{*}{$p$} \\
\hline & & $\begin{array}{c}\text { satisfactory } \\
{[\%]}\end{array}$ & $\begin{array}{l}\text { insufficient } \\
{[\%]}\end{array}$ & \\
\hline \multirow{2}{*}{ Gender } & female & 7 & 93 & \multirow{2}{*}{0.672} \\
\hline & male & 8 & 92 & \\
\hline \multirow{2}{*}{$\begin{array}{l}\text { Place } \\
\text { of residence }\end{array}$} & city & 5 & 95 & \multirow{2}{*}{1.000} \\
\hline & rural area & 8 & 92 & \\
\hline \multirow{2}{*}{ Type of school } & $\begin{array}{l}\text { senior } \\
\text { secondary } \\
\text { school }\end{array}$ & 10 & 90 & \multirow{2}{*}{0.436} \\
\hline & $\begin{array}{l}\text { technical } \\
\text { secondary } \\
\text { school }\end{array}$ & 4 & 96 & \\
\hline \multirow{3}{*}{$\begin{array}{l}\text { Participation } \\
\text { in Education } \\
\text { for Family Life } \\
\text { classes in senior } \\
\text { secondary } \\
\text { school/ } \\
\text { technical } \\
\text { secondary } \\
\text { school }\end{array}$} & in all classes & 8 & 92 & \multirow{3}{*}{1.000} \\
\hline & $\begin{array}{l}\text { in some } \\
\text { classes }\end{array}$ & 7 & 93 & \\
\hline & $\begin{array}{l}\text { no } \\
\text { participation } \\
\text { at all }\end{array}$ & 0 & 100 & \\
\hline \multirow{6}{*}{$\begin{array}{l}\text { Legitimacy } \\
\text { of natural family } \\
\text { planning classes } \\
\text { at school }\end{array}$} & definitely not & 0 & 100 & \multirow{6}{*}{0.215} \\
\hline & probably not & 0 & 100 & \\
\hline & $\begin{array}{l}\text { I do not } \\
\text { know }\end{array}$ & 29 & 71 & \\
\hline & rather yes & 4 & 96 & \\
\hline & definitely yes & 9 & 91 & \\
\hline & no & 7 & 93 & \\
\hline \multirow{2}{*}{$\begin{array}{l}\text { Having friends } \\
\text { who became } \\
\text { parents under } \\
\text { the age of } 18\end{array}$} & yes & 7 & 93 & \multirow{2}{*}{1.000} \\
\hline & no & 7 & 93 & \\
\hline
\end{tabular}

Table 1. The levels of students' knowledge in individual question categories and in total

Tabela 1. Poziomy wiedzy uczniów w poszczególnych kategoriach pytań i ogółem

\begin{tabular}{|c|c|c|c|c|}
\hline Question categories & Insufficient [\%] & Satisfactory [\%] & Good [\%] & Very good [\%] \\
\hline Knowledge about the menstrual cycle & 71 & 25 & 4 & 0 \\
\hline Knowledge about natural family planning & 65 & 20 & 11 & 4 \\
\hline Knowledge about the thermal method & 83 & 17 & 0 & 0 \\
\hline Knowledge about the mucus method & 88 & 11 & 1 & 0 \\
\hline Knowledge about the cervical observation & 59 & 24 & 14 & 3 \\
\hline Total & 93 & 7 & 0 & 0 \\
\hline
\end{tabular}


subject are "definitely" necessary for young people. According to the students, natural family planning classes should be run by a doctor (54\%), a nurse (46\%) and a school teacher (45\%). The most appropriate place for natural family planning classes is school (74\%) and gynecological outpatient clinics (63\%). In the opinion of $66 \%$ of the students, education on this subject should start at the age of 14-16 years. The results are shown in Table 3.

Table 3. Students' opinon on the organization of natural family planning classes

Tabela 3. Opinie uczniów na temat organizacji zajęć z zakresu naturalnego planowania rodziny

\begin{tabular}{|c|c|c|}
\hline Question & Answers & $\%$ \\
\hline \multirow{5}{*}{$\begin{array}{l}\text { Legitimacy of natural family } \\
\text { planning classes at school } \\
\text { in students' opinion }\end{array}$} & definitely not & 5 \\
\hline & probably not & 7 \\
\hline & I do not know & 7 \\
\hline & rather yes & 48 \\
\hline & definitely yes & 33 \\
\hline \multirow{7}{*}{$\begin{array}{l}\text { Students' opinion on a natural } \\
\text { family planning educator }\end{array}$} & parent & 14 \\
\hline & nurse & 46 \\
\hline & school teacher & 45 \\
\hline & class tutor & 16 \\
\hline & $\begin{array}{l}\text { non-school } \\
\text { educator }\end{array}$ & 27 \\
\hline & doctor & 54 \\
\hline & other person & 3 \\
\hline \multirow{6}{*}{$\begin{array}{l}\text { Students' opinion on the place } \\
\text { of natural family planning } \\
\text { education }\end{array}$} & home & 21 \\
\hline & school & 74 \\
\hline & $\begin{array}{l}\text { gynecological } \\
\text { outpatient clinic }\end{array}$ & 63 \\
\hline & $\begin{array}{l}\text { family doctor } \\
\text { surgery }\end{array}$ & 20 \\
\hline & church & 11 \\
\hline & other places & 0 \\
\hline \multirow{5}{*}{$\begin{array}{l}\text { Students' opinion on the age } \\
\text { at which natural family planning } \\
\text { education should begin }\end{array}$} & no data available & 3 \\
\hline & $\begin{array}{l}10-13 \text { years } \\
\text { (primary school) }\end{array}$ & 13 \\
\hline & $\begin{array}{l}\text { 14-16 years } \\
\text { (junior secondary } \\
\text { school) }\end{array}$ & 66 \\
\hline & $\begin{array}{l}\text { 17-19 years } \\
\text { (senior secondary } \\
\text { school) }\end{array}$ & 10 \\
\hline & $>20$ years & 8 \\
\hline
\end{tabular}

Fourty percent of the students "do not really" acquire information on natural family planning at the moment, while $11 \%$ "definitely not". The sources used by students to find information on natural family planning include the Internet (49\%), magazines (33\%) and advice from friends (26\%). The willingness to take part in natural family planning classes at school was "rather yes" confirmed by $50 \%$ of the students and "definitely yes" by $20 \%$.

\section{Discussion}

The implementation of sex education among children and youth at schools still raises a lot of controversy in the society. Studies conducted by the Centre for Public Opinion Research (Warszawa, Poland) on the legitimacy of introducing sex education into schools have shown that $90 \%$ of the society supports such decision. ${ }^{11}$ The participants of the study conducted by Zawadzka and Nowak demonstrated the acceptance of sex education at schools at a slightly lower level (70\%). ${ }^{12}$

According to data published by the Ministry of National Education from 2012, 75\% of junior secondary school students, $37 \%$ of senior secondary school students and $51 \%$ of technical secondary school students attended Education for Family Life classes. Twenty-nine percent of senior secondary school students and $45 \%$ of technical secondary school students declared participation in Education for Family Life classes during the $3^{\text {rd }}$ year of school. ${ }^{13}$ A decrease of the proportion of students attending Education for Family Life classes at subsequent educational levels from about $90 \%$ in primary and junior secondary school to $70 \%$ in senior secondary school was also reported in the studies conducted by the Ponton group. ${ }^{14}$ The analysis of our results indicates that a total of $60 \%$ of junior secondary school students and $70 \%$ of senior secondary school and technical secondary school students had attended Education for Family Life classes. The data analysis conducted by the Ponton group showed that young people participated in the classes mainly because the subject was obligatory or they were driven by curiosity and the willingness to acquire knowledge. In senior secondary school, the subject was the most rarely organized and the least frequented. According to the youth, the organization and manner of running the classes was often unsatisfactory. ${ }^{14}$

Both in our studies (73\% of the subjects) and those conducted by Boguszewski et al. (62\% of the subjects), most students confirmed that they had friends who had become parents under the age of $18 .^{15}$ The slight difference between the results may be due to the fact that our research included students from 1 school and not from several schools, as in the case of the compared study. Most of the students who declared to have friends who became parents under the age of 18 have common colleagues; therefore this data may be slightly overstated.

Our research, which was based on the analysis of 5 questions examining knowledge of the menstrual cycle, showed a very low level of the students' knowledge. This in some way contradicts the subjective assessment of the level of senior secondary school students' knowledge conducted by Kanadys et al. Fourteen percent of the subjects claimed that they had a high level of knowledge and $61 \%$ believed their level of knowledge was satisfactory. ${ }^{16}$ The studies also demonstrated that less than $60 \%$ of the subjects knew that the appearance of bleeding marks the $1^{\text {st }}$ day 
of the menstrual cycle. ${ }^{16}$ Our research shows that only $18 \%$ of the students can correctly form the phases of the menstrual cycle in a sequence. The appearance of bleeding as the $1^{\text {st }}$ day of the menstrual cycle was correctly indicated by only $41 \%$ of the subjects.

Both our study and those conducted by the abovementioned authors showed no statistically significant relationship between variables such as sex or place of residence and the level of students' knowledge about the menstrual cycle. The studies conducted by Ching-Yu et al. have confirmed considerable gender differences. Girls knew more about the menstrual cycle than boys. ${ }^{17}$

In the studies conducted by Sieńko and Stokłosa, $63 \%$ of the subjects correctly classified the thermal method and $42 \%$ the Billings method as natural family planning methods, while $20 \%$ of the subjects correctly classified both methods. ${ }^{6}$ In our study, $54 \%$ of the students gave the correct answer that coitus interruptus was not a natural family planning method.

Most literature publications deal with contraception, the sexual initiation and sexuality awareness of young people; few reports describe the level of teenagers' knowledge about natural family planning. Even though in the Ponton report $52 \%$ of subjects indicated that the issues of natural family planning were raised during Education for Family Life classes, our research demonstrated a very low level of students' knowledge. ${ }^{14}$

The study conducted by Łepecka-Klusek et al. showed that the Internet (64\%), magazines (59\%), peers (50\%), partners $(27 \%)$, television (26\%), and parents (21\%) are the main sources of knowledge about sexual life for young people. ${ }^{18}$ Our research seems to confirm this observation. Teachers, doctors and nurses were rarely the source of information. The results of the study conducted by Avril et al. showed that healthcare professionals were the source of knowledge about menstruation for only $2 \%$ of young people. ${ }^{19}$ According to the Ponton report, people who ran Education for Family Life classes most frequently referred to a helpline as the source of knowledge and the information they conveyed was often superficial and not substantiated. ${ }^{14}$ Young people claimed that they prefer to use the Internet rather than spend extra, boring hours at school.

In the opinion of $60 \%$ of adult Poles, the responsibility for spreading knowledge about human sexuality lies equally with school and parents. ${ }^{11}$ The results of our research show that students prefer to obtain knowledge about natural family planning from a doctor (54\%), a nurse (46\%), a teacher (45\%), or a non-school educator (27\%), and to a small extent from a parent (14\%). It is therefore necessary to recognize the need to support parents in the implementation of sex education by educational institutions and healthcare organizations.

In its study, the Centre for Public Opinion Research asked adult Poles when young people should start their sexual education. The results of this study overlap with the outcomes of our research, which dealt with the age at which young people should begin their natural family planning education. According to adult Poles, the optimal age was about 14 years, while the age indicated by students oscillated in the range of $14-16$ years (66\% of the subjects). ${ }^{11}$ The Ponton report showed that, in the opinion of $49 \%$ of the subjects, Education for Family Life classes were run at the right age, i.e., at a time when young people began to be interested in sexuality. Every third person believed that the classes were run too late. ${ }^{14}$ Most of the people (89\%) who participated in this study believed that sex education classes were needed in schools. In our research, as many as $81 \%$ of the students believed that it was reasonable to run natural family planning classes at school.

\section{Conclusions}

The insufficient level of students' knowledge about natural family planning justifies the need to include this subject in the curriculum of senior secondary school on a scope broader than before.

It is necessary to engage healthcare institutions and professionals in natural family planning education on a scope larger than before.

The school is a good place for natural family planning classes.

A students' willingness to attend natural family planning classes can be a factor that favors their active participation in the education, and thus can contribute to achieving better results.

\section{References}

1. Domżał-Drzewicka R, Gałęziowska E, eds. Nowoczesne metody rozpoznawania płodności - wybrane zagadnienia. Lublin, Poland: Wydawnictwo MakMed; 2007.

2. Stadnicka G, ed. Opieka przedkoncepcyjna. Warszawa, Poland Wydawnictwo PZWL; 2009.

3. Skrzypulec V, Drosdzol A. Antykoncepcja dziewcząt i młodych kobiet. Ginekol Dypl. 2009;11(3):29-32.

4. GUS. Baza Demografia. 2014. demografia.stat.gov.pl/bazademografia/. Accesed November 15, 2017.

5. Imacka J, Bulsa M. Świadomość seksualna młodzieży w polskiej rzeczywistości. Probl Hig Epidemiol. 2012;93(3):453-456.

6. Sieńko K, Stokłosa K. Wiedza o antykoncepcji i zachowania seksualne nastolatek w wieku 16-19 lat. Położna Nauka i Praktyka. 2014;3(27):10-16.

7. Rozporządzenie Ministra Edukacji Narodowej z dnia 27 sierpnia 2012 r. w sprawie podstawy programowej wychowania przedszkolnego oraz kształcenia ogólnego w poszczególnych typach szkół. Dz. U. z 2012 r., poz. 977.

8. Długołęcka A. Seksualność - wybrane zagadnienia. In: Woynarowska B, ed. Edukacja zdrowotna - podręcznik akademicki. Warszawa, Poland: Wydawnictwo Naukowe PWN; 2008:344.

9. Rozporządzenie Ministra Edukacji Narodowej z dnia 10 sierpnia 2009 r. zmieniające rozporządzenie w sprawie sposobu nauczania szkolnego oraz zakresu treści dotyczących wiedzy o życiu seksualnym człowieka, o zasadach świadomego i odpowiedzialnego rodzicielstwa, o wartości rodziny, życia w fazie prenatalnej oraz metodach i środkach świadomej prokreacji zawartych w podstawie programowej kształcenia ogólnego. Dz. U. Nr 131, poz. 1079. 
10. Borzucka-Sitkiewicz K. Edukacja seksualna. In: Syrek E, Borzucka-Sitkiewicz K, eds. Edukacja zdrowotna. Warszawa, Poland: Wydawnictwo Akademickie i Profesjonalne; 2009:153-172.

11. CBOS. O wychowaniu seksualnym młodzieży - komunikat $z$ badań. Warszawa, Poland: CBOS; 2007:2-4.

12. Zawadzka B, Nowak E. Przygotowanie nauczycieli w zakresie edukacji zdrowotnej na przykładzie woj. świętokrzyskiego. Wychowanie Fizyczne i Zdrowotne. 2006;2:31-36.

13. Sprawozdanie Rady Ministrów z wykonywania oraz o skutkach stosowania w roku 2012 ustawy z dnia 7 stycznia 1993 r. o planowaniu rodziny, ochronie płodu ludzkiego i warunkach dopuszczalności przerywania ciąży. Warszawa, Poland: 2014:47-48.

14. Grupa Edukatorów Seksualnych Ponton. Raport grupy edukatorów seksualnych Ponton, Sprawdzian (z) WdŻ, czyli jak wygląda edukacja seksualna w polskich szkołach. Warszawa, Poland; 2014.

15. Boguszewski R, Feliksiak M, Gwiazda M, Kalka J. Młodzież o sobie: wartości, obyczajowość, grupy odniesienia. In: CBOS - młodzież 2013. Warszawa, Poland: CBOS; 2014:133-138.

16. Kanadys K, Lewicka M, Niziołek I, Bąk M, Stawarz B, Wiktor H. Subiektywna ocena wiedzy młodzieży licealnej w zakresie fizjologii cyklu miesiączkowego kobiety. Probl Pielęg. 2010;18(3):292-298.

17. Ching-Yu Ch, Kyeongra Y, Shwu-Ru L. Taiwanese adolescents' gender differences in knowledge and attitudes towards menstruation. Nurs Health Sci. 2007;9(2):127-134.

18. Łepecka-Klusek C, Baładna-Bałdyga A, Stadnicka G, Marczak E. Wczesna inicjacja seksualna w grupie nastoletnich matek. Zdr Publ. 2012;122(2):181-184.

19. Avril MH, Anisha A, Zhihuan H, Lawrence JD. Knowledge, attitudes, and consequences of menstrual health in urban adolescent females. J Pediatr Adolesc Gynecol. 2006;19(4):271-275. 